\title{
PENALAAN OPTIMAL KONTROLER PSS-PID PADA SISTEM SINGLE MACHINE INFINITE BUS MENGGUNAKAN ANT COLONY OPTIMIZATION
}

\author{
Muhammad Ruswandi Djalal ${ }^{1}$, Nasrun Kadir ${ }^{2}$ \\ 1,2Jurusan Teknik Mesin, Politeknik Negeri Ujung Pandang \\ Makassar, Indonesia \\ e-mail: wandi@poliupg.ac.id ${ }^{1}$, nasrun_kadir@poliupg.ac.id ${ }^{2}$
}

\begin{abstract}
Abstrak
Perubahan beban pada sistem tenaga listrik secara tiba-tiba menyebabkan terjadinya gangguan dinamik. Gangguan tersebut menyebabkan kestabilan generator terganggu, karena generator tidak merespon gangguan tersebut secara cepat. Hal ini menyebabkan terjadinya osilasi pada generator berupa osilasi frekuensi dan sudut rotor. Salah satu peralatan kontrol tambahan yang mampu meningkatkan kestabilan suatu generator adalah Power Sistem Stabilizer (PSS) dan Proportional Integral Derrivative (PID). Dalam aplikasinya, penentuan parameter kontroler ini masih menggunakan metode trial \& error, metode ini sangat sulit untuk mendapatkan parameter yang tepat. Dengan menggunakan metode cerdas berbasis Ant Colony didapatkan parameter PSS-PID yang optimal. Dengan penalaan optimal didapatkan respon frekuensi dan sudut rotor sistem SMIB yang optimal, ditunjukkan dengan respon overshot sistem yang minimum. Kontroler mampu memberikan kestabilan sehingga osilasi overshoot dapat diredam, serta kinerja settling time yang semakin cepat untuk sistem menuju ke kondisi steady state. Untuk menguji kestabilan sistem SMIB digunakan studi kasus penambahan dan pengurangan beban, dengan metode kontrol yang diusulkan PSS-PID yang dioptimasi menggunakan Ant Colony.
\end{abstract}

Kata Kunci: PSS, PID, Ant Colony, SMIB, Settling Time, Overshoot.

\begin{abstract}
Changes in the load on the electric power system suddenly, causing dynamic disturbance. The disturbance causes the stability of the generator to be disturbed, because the generator does not respond to the disturbance quickly. This causes oscillations in the generator in the form of frequency oscillations and rotor angles. One additional control device that is able to increase the stability of a generator is the Power System Stabilizer (PSS) and Proportional Integral Derrivative (PID). In its application, the determination of controller parameters is still using the trial \& error method, this method is very difficult to get the right parameters. By using the smart method based on Ant Colony, the optimal PSS-PID parameters are obtained. With optimal tuning we get the optimal SMIB system frequency and rotor angle response, indicated by the minimum overshot system response. The controller is able to provide stability so that overshoot oscillations can be muted, as well as faster settling time performance for the sistem to go to steady state. To test the stability of the SMIB sistem a case study of adding and reducing loads is used, with the proposed control method PSS-PID being optimized using Ant Colony.
\end{abstract}

Keywords: PSS, PID, Ant Colony, SMIB, Settling Time, Overshoot.

\section{PENDAHULUAN}

Dalam studi kestabilan dinamik, diasumsikan bahwa perubahan torsi akibat respon governor diabaikan karena respon governor sangat lambat dibandingkan dengan respon sistem eksitasi, sehingga faktor pengendali pada sistem eksitasi. Penambahan rangkaian eksitasi penguat kurang mampu menstabilkan sistem terutama untuk osilasi frekuensi rendah. Low Frequency Oscillation antara 0.2 - 2.0 $\mathrm{Hz}$ (Kundur).

Frekuensi yang lebih rendah dapat diperluas menjadi osilasi antar area sehingga diperlukan kontrol tambahan seperti kontrol Power Sistem Stabilizer (PSS) dan Proportional Integral Derrivative (PID). PSS merupakan peralatan kontrol Jurnal Sains dan Teknologi | 75 
tambahan pada eksitasi generator yang digunakan untuk memberi redaman tambahan pada eksitasi generator (Djalal, Yunus, Setiadi, \& Krismanto, 2018; Yunus, Djalal, \& Marhatang, 2017). PID adalah alat kontrol tambahan yang berfungsi untuk mengurangi osilasi lokal atau global pada generator, sebagai respon terhadap penyimpangan yang terjadi pada nilai variabel yang telah ditetapkan (Djalal, Imran, \& Robandi, 2015; Djalal, Setiadi, Lastomo, \& Yunus, 2017). Untuk mendapatkan hasil yang maksimal, diperlukan penyetelan PSS dan PID yang tepat dan optimal untuk mengurangi osilasi dan menstabilkan sistem. Penalaan parameter ini dapat menggunakan optimasi metode cerdas, atau yang biasa disebut kecerdasan buatan.

\section{Ant Colony Optimization (ACO)}

termasuk dalam kelompok Swarm Intelligence, yang merupakan salah satu jenis pengembangan paradigma yang digunakan untuk menyelesaikan masalah optimisasi dimana inspirasi yang digunakan untuk menyelesaikan masalah berasal dari perilaku kelompok atau serangga yang berkerumun (Aliklas, Satyahadewi, \& Perdana; Djalal \& Faisal, 2020). Penggunaan metode ACO juga digunakan dalam penelitian ini sebagai metode untuk menyempurnakan parameter kontrol PID (Muhammad \& Herman, 2019; Yunus \& Djalal, 2019). Beberapa penelitian telah menjelaskan tentang penerapan metode cerdas untuk mengoptimalkan parameter kontrol generator dan hasil yang diberikan kepada sistem sangat baik dalam menjaga stabilitas generator, seperti metode firefly (Yunus et al., 2017), bat algorithm (Djalal, Yunus, Nawir, \& Imran, 2017; Suharto, 2015), flower pollination (Djalal \& Sonong, 2018), imperialist competitive (Djalal et al., 2015), and cuckoo search (Djalal, Setiadi, et al., 2017; Djalal et al., 2018).

Penalaan parameter yang optimal dari kontroler akan sangat berpengaruh dalam menstabilkan sistem. Namun range parameter peralatan sangat beragam dan luas, maka untuk memperoleh nilai parameter secara cepat digunakanlah metode optimisasi menggunakan ACO. Nilai respon diketahui dengan menganalisis nilai overshoot dan settling time, sedangkan untuk objective function meminimalkan Integral Time Absolute Error (ITAE). Studi kasus yang digunakan adalah sistem Single Machine Infinite Bus (SMIB). SMIB merupakan subsistem tenaga listrik yang terdiri dari satu atau lebih generator yang terhubung ke bus yang tak terhingga (Laksono \& Putra, 2013). Kemudian Menganalisa hasil simulasi dengan cara membandingkan hasil simulasi sistem tanpa kontrol, SMIB dengan PID, SMIB dengan PSS dan dengan metode yang diusulkan SMIB dengan PSS-PID dengan ACO. Pada penelitian ini penulis mengimplementasikan metode cerdas berbasis ant colony untuk menyelesaikan permasalahan optimasi penentuan parameter PSS-PID pada sistem SMIB.

\section{METODE}

Terdapat beberapa langkah pelaksanaan penelitian yang dimulai dengan studi literatur, analisis dan kesimpulan, sebagai berikut :

\section{a. Analisis Data}

Studi kasus yang digunakan adalah sistem single machine infinite bus (SMIB) dengan mengacu pada pemodelan penelitian sebelumnya (Robandi, 2009) Beberapa tahapan analisa yaitu, pemodelan sistem mesin sinkron, pemodelan PSS-PID menggunakan simulink, memasukkan data sistem, desain algoritma ant colony, dan plotting hasil pemasangan PSS-PID dan dibandingkan dengan skema kontrol lain.

\section{b. Pemodelan Sistem}

Pemodelan mesin sinkron dimodelkan kedalam bentuk pemodelan linier. Ditunjukkan pada Gambar 1 (Robandi, 2009).

\section{c. Pemodelan Eksitasi}

Peralatan eksitasi adalah salah satu bagian sistem yang di mana dengan eksiter ini dapat mengatur variabel output generator, seperti tegangan, arus dan faktor daya (Yunus et al., 2017). Model eksitasi mengacu pemodelan IEEE 
ditunjukkan pada Gambar 2 (Robandi, 2009).

\section{d. Pemodelan Governor}

Governor adalah sebuah kontroler yang berfungsi untuk mengatur nilai torsi mekanik Tm yang menjadi input dari generator (Robandi, 2009). Pemodelan ditunjukkan pada Gambar 3.

\section{e. Pemodelan Turbin}

Pemodelan turbin digunakan adalah model turbin pembangkit listrik tenaga uap, dari model IEEE (Padiyar, 1996). Pemodelan ditunjukkan pada Gambar 4. f. Pemodelan Single Machine Infinite Bus (SMIB)

Pemodelan keseluruhan sistem ditunjukkan pada model Sinle Machine Infinite Bus 5 (Suharto, 2015).

g. Pemodelan Power System Stabilizer

Power Sistem Stabilizer merupakan suatu peralatan yang dapat digunakan untuk meningkatkan stabilitas sistem tenaga. Pemodelan PSS pada penelitian ini ditunjukkan pada Gambar 6.

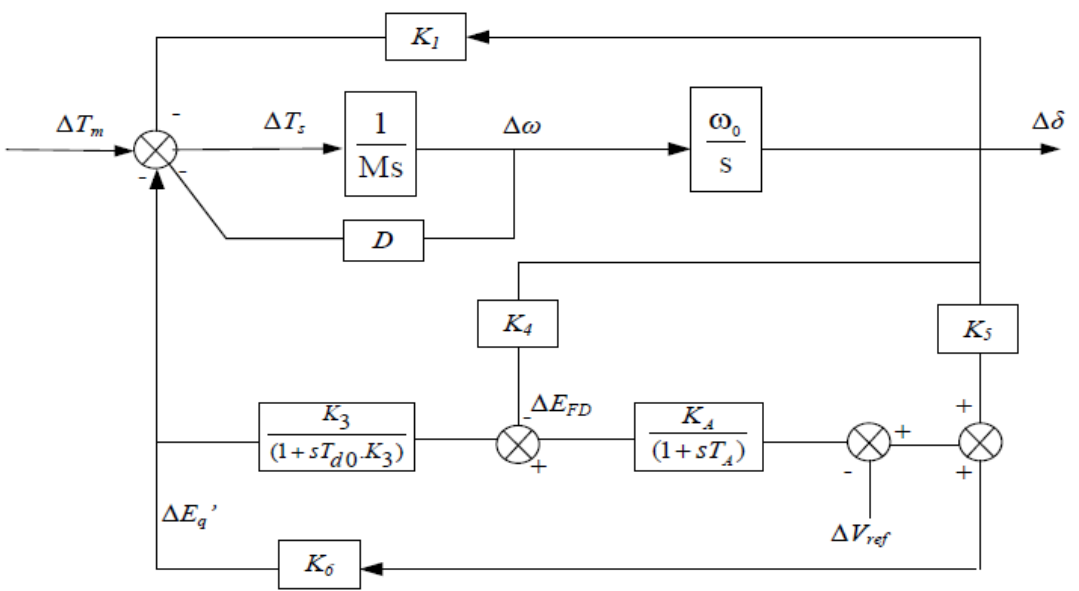

Gambar 1. Pemodelan Linier Mesin Sinkron

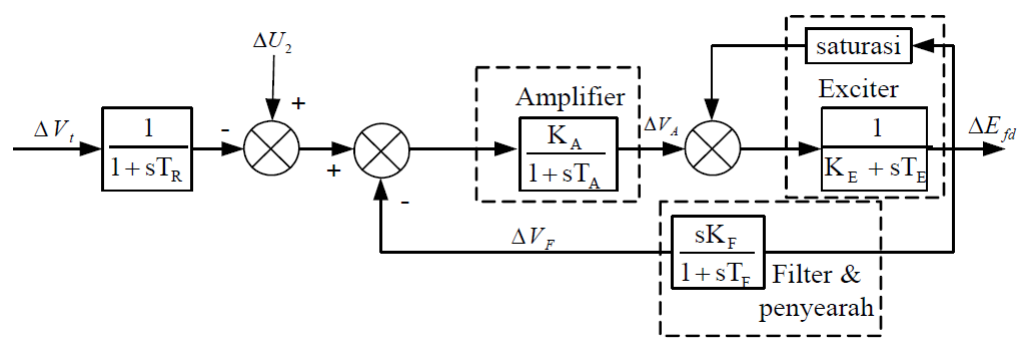

Gambar 2. Block Diagram Eksitasi

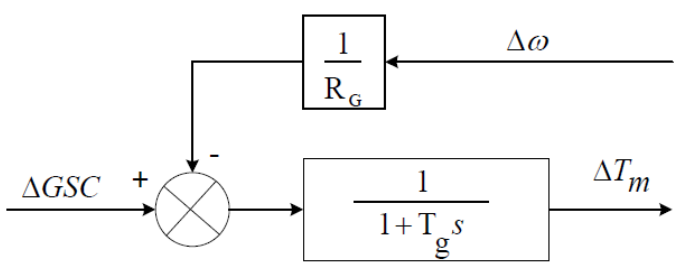

Gambar 3. Pemodelan Governor 


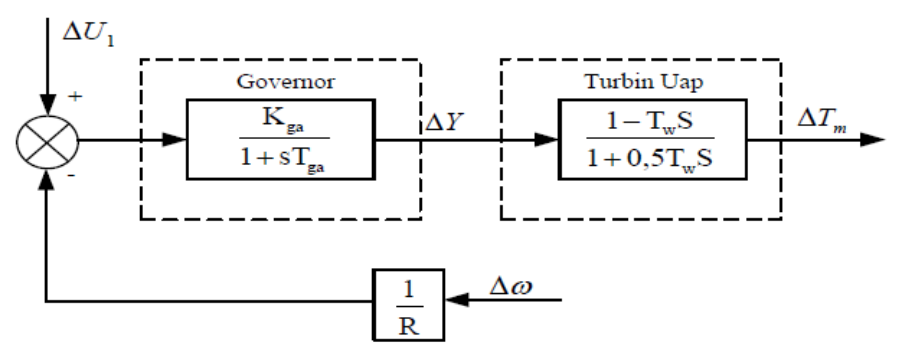

Gambar 4. Pemodelan Turbin

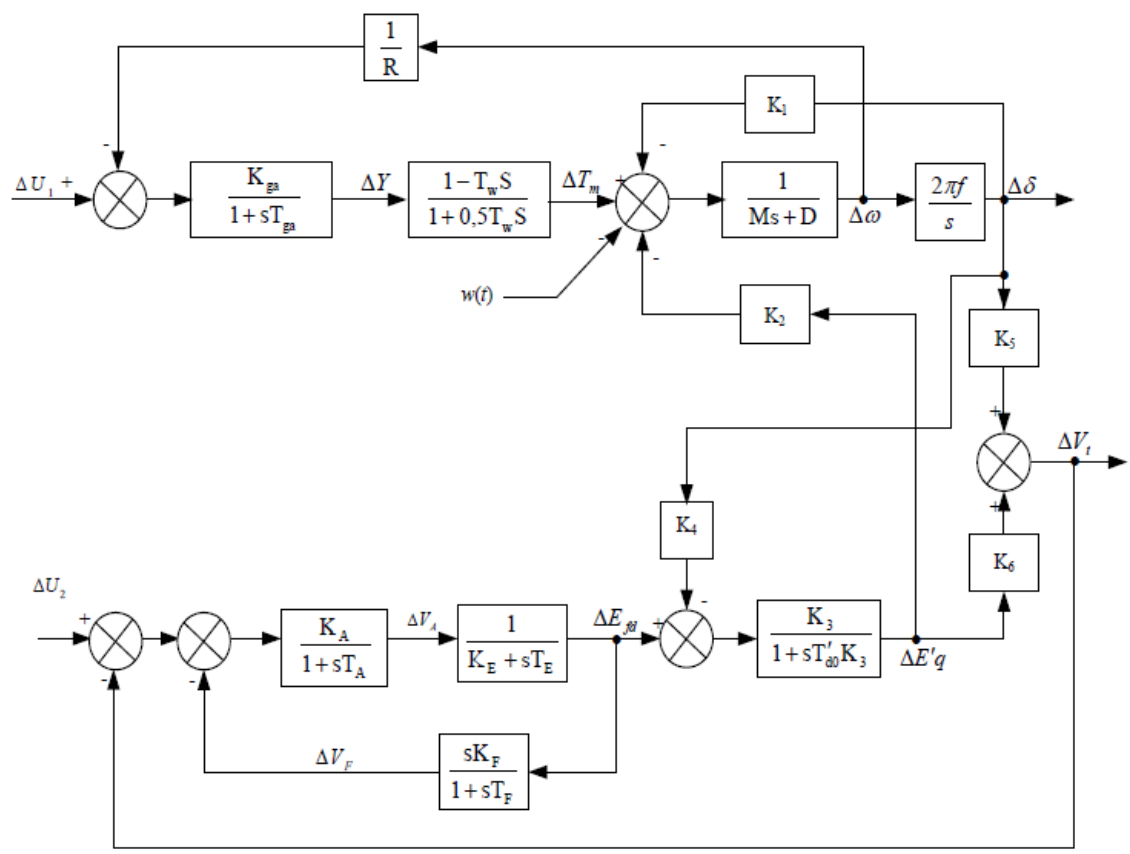

Gambar 5. Pemodelan SMIB

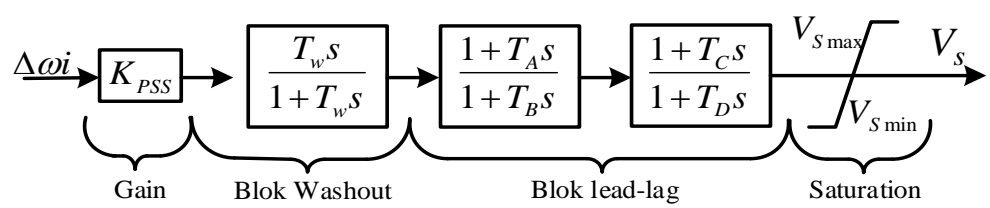

Gambar 6. Pemodelan PSS

h. Ant Colony Optimization

Penentuan Jarak Antar Kota

Kota yang dimaksud di sini adalah besarnya nilai pembangkitan dari masingmasing pembangkit. Sebelum dilakukan perjalanan, jarak antara nilai dari pembangkitan pembangkit yang satu dengan pembangkit yang lainnya dihitung terlebih dahulu (diinisialisasi). Setelah dilakukan inisialisasi, maka semut diletakkan di kota pertama tertentu secara acak. Kemudian semut akan melanjutkan perjalanannya dari satu kota ke kota yang lainnya secara acak sampai ke tujuan akhir, yaitu kota terakhir. Setelah perjalanan selesai, lokasi kota-kota yang telah dilalui oleh semut akan digunakan untuk menghitung solusi yang dihasilkan dari perjalanan tersebut .

\section{Perjalanan Semut}

Semut memilih suatu jalur yang akan dilalui mulai dari titik $r$ menuju ke titik $s$ dalam suatu perjalanan dengan probabilitas:

$$
\mathrm{p}(\mathrm{r}, \mathrm{s})=\frac{\gamma(\mathrm{r}, \mathrm{s})}{\sum_{\mathrm{t}} \gamma(\mathrm{r}, \mathrm{l})} \mathrm{s}, 1 \in \mathrm{N}_{\mathrm{r}}^{\mathrm{k}}
$$

matrix $Y(r, s)$ merepresentasikan jumlah intensitas feromon antara titik $r$ dan $s$. Jurnal Sains dan Teknologi | 78 
Kemudian feromon akan diperbaharui melalui persamaan berikut :

$$
\gamma(\mathrm{r}, \mathrm{s})=\alpha \cdot \gamma(\mathrm{r}, \mathrm{s})+\Delta \mathrm{y}^{\mathrm{k}}(\mathrm{r}, \mathrm{s})
$$

dimana $\alpha$ dengan interval $0<\alpha<1$ merupakan daya tahan suatu feromon, maka (1- a) merepresentasikan penguapan yang terjadi pada feromon dan $\Delta \gamma^{k}(r, s)$ merupakan jumlah feromon yang semut $k$ jatuhkan pada jalur $(r, s)$.

Perbaharui Feromon Lokal

Jejak feromon $(r, s)$ untuk perjalanan terbaik yang telah dilakukan semut (semut yang menghasilkan parameter optimal PID) akan diperbaharui dengan menggunakan persamaan berikut.

$$
\gamma(\mathrm{r}, \mathrm{s})=\alpha \cdot \gamma(\mathrm{r}, \mathrm{s})+\frac{\mathrm{Q}}{\mathrm{f}_{\text {best }}} \mathrm{r}, \mathrm{s} \in \mathrm{J}_{\text {best }}^{\mathrm{k}}
$$

dengan $Q$ merupakan sebuah konstanta positif yang sangat besar nilainya.

Perbaharui Feromon Global

Untuk menghindari terjadinya stagnan (suatu situasi dimana semut akan mengikuti jalur yang sama, yang mana akan menghasilkan solusi yang sama), maka kekuatan jejak feromon dibatasi pada interval berikut :

$$
\gamma(\mathrm{r}, \mathrm{s})=\left\{\begin{array}{c}
\tau_{\min } \text { if } \gamma(\mathrm{r}, \mathrm{s}) \leq \tau_{\min } \\
\tau_{\max } \text { if } \gamma(\mathrm{r}, \mathrm{s}) \geq \tau_{\max }
\end{array}\right\}
$$

Batasan atas dan batas bawahnya adalah sebagai berikut :

$$
\begin{aligned}
\tau_{\max } & =\frac{1}{\alpha \cdot f_{\text {best }}} \\
\tau_{\text {min }} & =\frac{\tau_{\text {max }}}{M^{2}}
\end{aligned}
$$

dengan $M$ adalah jumlah semut yang melakukan perjalanan.

Plot Perjalanan Semut

Solusi dari perjalanan koloni semut dalam optimasi parameter PSS-PID diplot ke dalam sebuah grafik sampai batas maksimum iterasi.
Plot Perjalanan Terbaik

Perjalanan dengan solusi terbaik dari koloni semut (parameter optimal PSS-PID) untuk setiap iterasi diplot sampai batas iterasi maksimum.

Flowchart Ant Colony Optimization

Diagram alir dari metode Ant Colony Optimization yang digunakan untuk mencari parameter optimal PSS-PID ditunjukkan pada gambar 4.

\section{Parameter Ant Colony Optimization}

Beberapa parameter yang digunakan pada metode Ant Colony Optimization pada tesis ini adalah sebagai berikut:

- Jumlah semut $=10$

- Iterasi maksimum = 50

- Ketahan feromon (alpha) $=0.9$

Inisialisasi Feromon (Matriks Tau)

Matriks tau ini memiliki ukuran nxm, dengan n adalah banyaknya kontroler pada sistem, sedangkan $\mathrm{m}$ adalah banyaknya parameter PID dengan skala 0 sampai dengan 1 yang memiliki interval 0,01. Nilai dari matriks ini akan diperbaharui setiap dilakukan perjalanan oleh koloni semut.

i. Penalaan Kontrol PSS-PID dengan Ant Colony

Gambar 7 menunjukkan diagram alir algoritma metode Ant Colony yang digunakan pada penelitian ini untuk menala parameter PSS-PID. Fungsi objektif yang digunakan untuk menguji kestabilan sistem adalah dengan Integral Time Absolut Error (ITAE).

$$
\text { ITAE }=\int_{0}^{t} t|\Delta \omega(t)| d t
$$

Parameter PSS-PID yang ditala oleh Ant Colony adalah Kp, Ki, Kd, Kpss, T1, T2, T3, T4. Adapun untuk diagram alir proses penalaan parameter PID dengan menggunakan metode Ant Colony ditunjukkan oleh flowchart pada Gambar 8. 


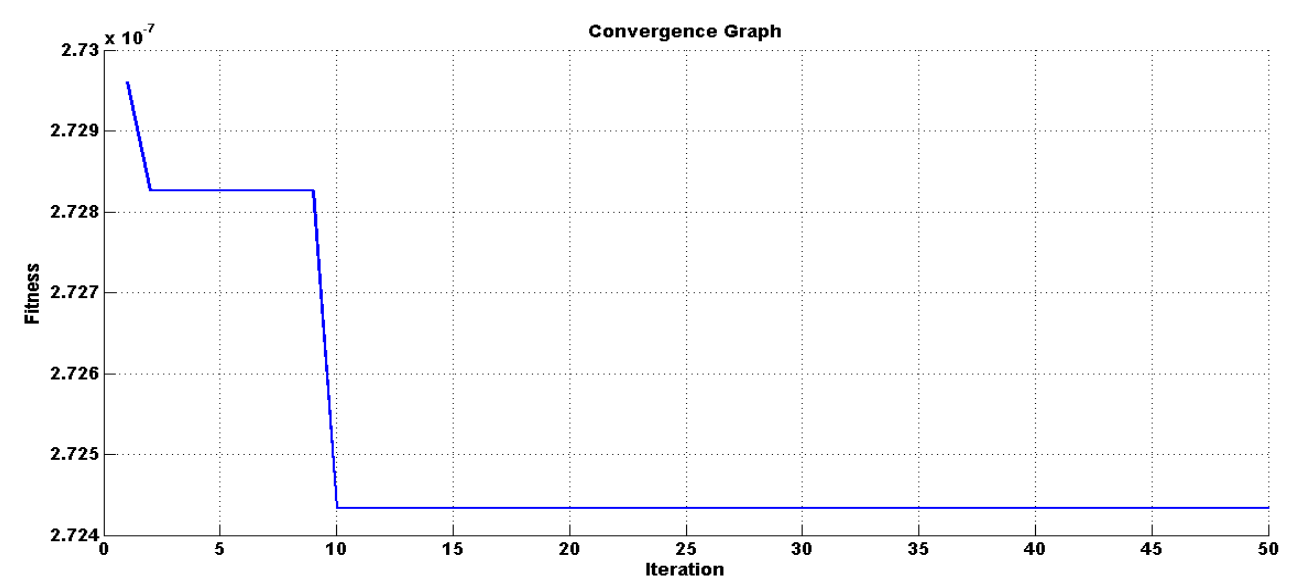

Gambar 7. Grafik Konvergensi

Untuk menjalankan algoritma Ant Colony dibutuhkan beberapa parameter, yang disebutkan pada table berikut ini. Algoritma ant colony dibuat menggunakan software Matlab (m.files) dan pemodelan SMIB menggunakan Simulink Matlab. Adapun data parameter-parameter ant colony adalah berikut,

Tabel 1. Parameter ant colony

\begin{tabular}{cc}
\hline Parameters & Values \\
\hline Number of Ants & 8 \\
Max Iteration & 50 \\
Feromone (Alpha) & 0.9 \\
Beta & 2 \\
\hline
\end{tabular}

Setelah memasukkan beberapa parameter tersebut di table di atas, maka selanjutnya algoritma ant colony dijalankan untuk optimasi nilai PSS-PID. Nilai yang tepat akan sangat mempengaruhi kinerja respon SMIB yang didesain pada penelitian ini. Algoritma ant colony membutuhkan proses perhitungan sampai menemukan nilai yang optimal. Gambar berikut menunjukkan grafik konvergensi optimasi nilai PID menggunakan algoritma ant colony. Konvergensi adalah suatu nilai fitness function yang menjabarkan kriteria optimal dari suatu masalah optimasi.

Gambar 7 menunjukkan grafik konvergensi optimasi nilai PSS-PID menggunakan ant colony, di mana berdasarkan grafik terlihat algoritma ant colony tidak membutuhkan waktu yang lama dalam melakukan proses optimasi, hal tersebut terlihat pada iterasi ke-10 algoritma sudah menemukan nilai PSS dan
PID yang optimal dengan nilai fitness sebesar 2.724e-07.

Hasil optimasi ant colony didapatkan nilai fitness function sebesar 2.724e-07, dengan 50 kali iterasi yang konvergen pada iterasi ke-10, nilai nbest merupakan ant colony terbaik, yang di mana diketahui sebagai hasil optimasi parameter PID, yaitu Kp, Ki, Kd, Kpss, T1, T2, T3, T4. Tabel 2 menunjukkan batasan dan nilai hasil optimasi parameter PSS-PID ditala oleh ant colony.

Tabel 2. Batasan dan Hasil Optimasi ACO

\begin{tabular}{cccc}
\hline \multirow{2}{*}{ Parameter } & \multicolumn{2}{c}{ Limits } & \multirow{2}{*}{ Results } \\
& Lower & Upper & \\
\hline Kp & 0 & 10 & 5.0311 \\
Ki & 0 & 100 & 1.1755 \\
Kd & 0 & 10 & 1.0043 \\
Kpss & 0 & 10 & 64.1961 \\
T1 & 0 & 10 & 0.5266 \\
T2 & 0 & 10 & 0.2317 \\
T3 & 0 & 10 & 1.0971 \\
T4 & 0 & 10 & 5.4010 \\
\hline
\end{tabular}

Sebagai pembanding digunakan beberapa skema kontrol, yaitu dengan PID, PSS dan kombinasi PSS-PID. Algoritma Ant Coloni pada prinsipnya mencari sumber makanan berdasarkan jejak feromone yang kemudian secara berkelompok akan mengikuti jejak yang memiliki feromone yang terbesar. Dengan prinsip ini algoritma akan mencari parameter yang paling optimal untuk diisikan pada parameter PID, sehingga didapatkan kendali optimal pada SMIB. 

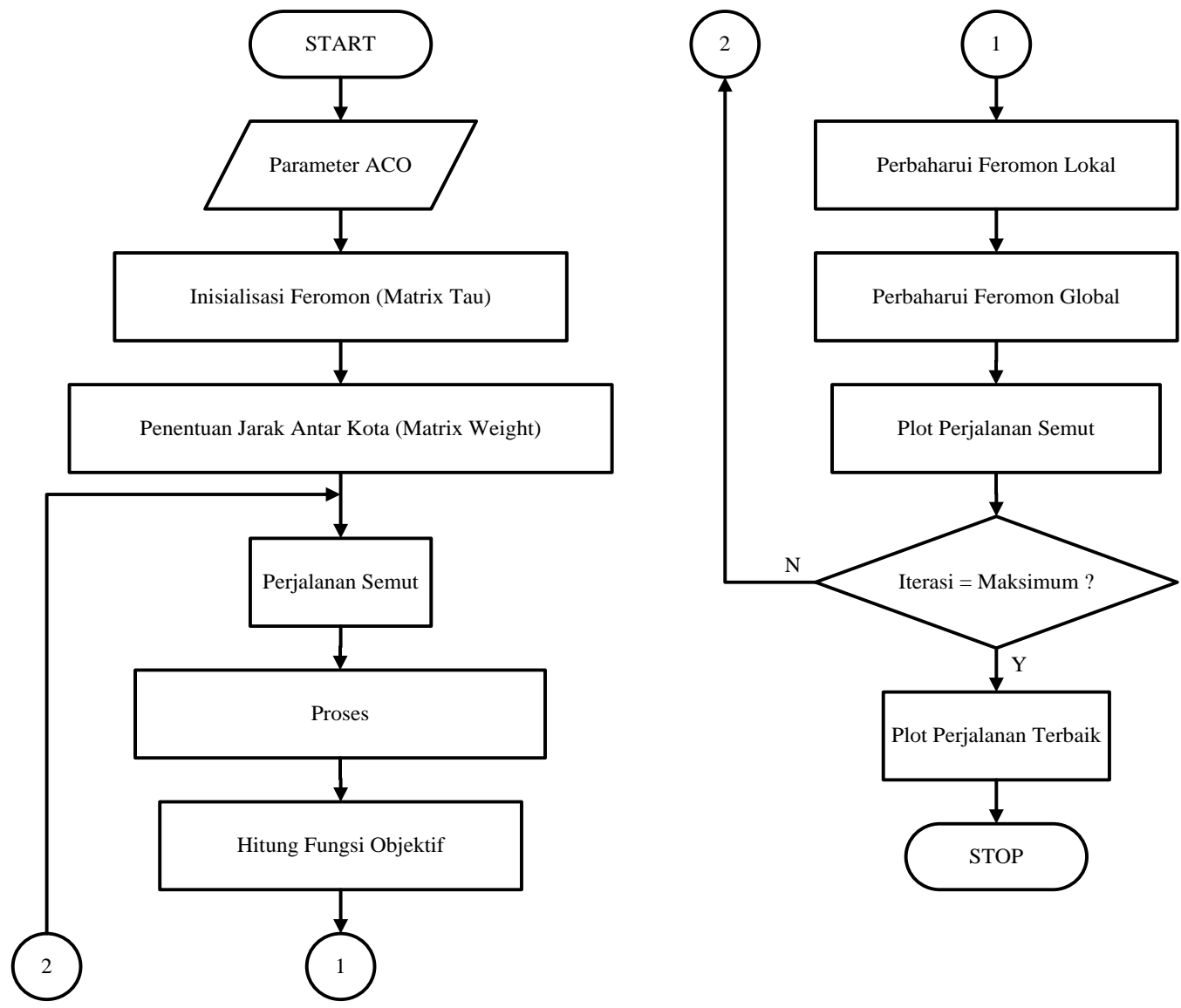

Gambar 8. Flowchart Ant Colony

\section{HASIL DAN PEMBAHASAN}

Analisa sistem dilakukan, yaitu analisa frekuensi sistem dan sudut rotor SMIB. Analisa dilakukan dengan beberapa pendekatan metode kontrol seperti sistem tanpa kontrol, SMIB-PID, SMIB-PSS, dan SMIB PSS-PID. Parameter PSS dan PID ditunning menggunakan algoritma Ant Colony Optimization. Untuk menguji kestabilan sistem, sistem SMIB diberi gangguan berupa perubahan beban.

\section{a. Respon Frekuensi SMIB}

Analisa pertama dimulai dengan meninjau respon kestabilan frekuensi sistem SMIB. Hasil simulasi ditunjukkan pada gambar 9. Gambar 9 menunjukkan hasil simulasi respon frekuensi SMIB dengan beberapa metode kontrol.

Dari hasil simulasi sistem SMIB diberi gangguan perubahan beban sebesar 0,01 pu pada detik ke 1, kemudian terjadi pelepasan beban pada detik ke 20 sebesar 0.005 pu. Pada perubahan beban pertama, terjadi penambahan beban, yaitu kondisi di mana daya elektris tidak sama dengan daya mekanis $(\mathrm{Pm})$ pada kondisi ini $\mathrm{Pe}>$ $\mathrm{Pm}$, sehingga antar torsi elektris dan torsi mekanis tidak seimbang. Kondisi ini menyebabkan frekuensi elektris $(\Delta \mathrm{f})$ juga berubah. Selama ketidakstabilan ini kecepatan putaran rotor $(\Delta \omega)$ menjadi tidak sinkron. Pada kondisi ini grafik respon frekuensi kebawah sebelum kembali ke steady state. Fungsi dari sistem kontrol kemudian diperlukan untuk mengembalikan ke kondisi steady state. Karakteristik respon overshoot pada kondisi ini ditunjukkan pada Tabel 2.

Tabel 2. Deviasi Frekuensi

\begin{tabular}{cc}
\hline Deviasi & Overshoot $(\mathrm{pu})$ \\
\hline SMIB & $-0.0002409 \& 0.0001865$ \\
SMIB-PID & $-0.0002069 \& 0.0002129$ \\
SMIB-PSS & $-0.0001748 \& 1.787 \mathrm{e}-05$ \\
SMIB-PSS-PID & $-0.0001533 \& 7.662 \mathrm{e}-05$ \\
\hline
\end{tabular}

Jurnal Sains dan Teknologi | 81 
Tabel 2 menunjukkan karakteristik overshoot sistem ketika terjadi perubahan beban pada detik ke-1 berupa penambahan beban. Sistem SMIB tanpa kontrol didapatkan overshoot sebesar -0.0002409 s/d 0.0001873 pu dengan settling time 15.09s. Sistem SMIB dengan kontrol PID didapatkan overshoot sebesar -0.0002069 $\mathrm{s} / \mathrm{d} 0.000131 \mathrm{pu}$ dengan settling time 11.78s. Sistem SMIB dengan kontrol PSS didapatkan overshoot sebesar -0.0001748 $\mathrm{s} / \mathrm{d}$ 8.743e-05 pu dengan settling time 2.334s. Kemudian dengan metode yang diusulkan menggunakan PSS-PID didapatkan overshoot yang paling kecil yaitu $-0.0001533 \mathrm{~s} / \mathrm{d} 7.662 \mathrm{e}-05$ pu dengan settling time 3.334s.

Kemudian pada perubahan beban berikutnya berupa pengurangan beban yang menyebabkan daya elektris $(\mathrm{Pe})$ berubah. Pada kondisi ini daya elektris tidak sama dengan daya mekanis (Pm) $\mathrm{Pe}$ $<$ Pm, sehingga antar torsi elektris dan torsi mekanis tidak seimbang. Kondisi ini menyebabkan frekuensi elektris $(\Delta \mathrm{f})$ juga berubah. Selama ketidakstabilan ini kecepatan putaran rotor $(\Delta \omega)$ menjadi tidak sinkron. Pada kondisi ini grafik respon frekuensi ke atas sebelum kembali ke steady state. Fungsi dari sistem kontrol kemudian diperlukan untuk mengembalikan ke kondisi steady state. Karakteristik respon overshoot pada kondisi ini ditunjukkan pada tabel 3. Gambar 9 merupakan grafik respon frekuensi elektris sistem $(\Delta f)$.

.Table 3. Deviasi Frekuensi

\begin{tabular}{cc}
\hline Deviasi & Overshoot $(\mathrm{pu})$ \\
\hline SMIB & $-9.314 \mathrm{e}-05 \& 0.0001203$ \\
SMIB-PID & $-6.515 \mathrm{e}-05 \& 0.000131$ \\
SMIB-PSS & $-9.369 \mathrm{e}-06$ \& 8.743e-05 \\
SMIB-PSS-PID & $-4.316 \mathrm{e}-06 \& 7.598 \mathrm{e}-05$ \\
\hline
\end{tabular}

Tabel 3 menunjukkan karakteristik overshoot sistem ketika terjadi perubahan beban pada detik ke-20 berupa pengurangan beban. Sistem SMIB tanpa kontrol didapatkan overshoot sebesar 9.314e-05 s/d 0.0001203 pu dengan settling time 32.17s. Sistem SMIB dengan kontrol PID didapatkan overshoot sebesar 6.515e-05 s/d 0.000131 pu dengan settling time 26.54s. Sistem SMIB dengan kontrol
PSS didapatkan overshoot sebesar 9.369e-06 s/d 8.743e-05 pu dengan settling time 23.13s. Kemudian dengan metode yang diusulkan menggunakan PSS-PID didapatkan overshoot yang paling kecil yaitu $-4.316 \mathrm{e}-06 \mathrm{~s} / \mathrm{d}$ 7.598e-05 pu dengan settling time 22.01s.

b. Respon Sudut Rotor

Analisa berikutnya, melihat kinerja respon sudut rotor SMIB dengan pemasangan kontrol PSS-PID. Pada penelitian ini pengujian pada SMIB diberikan berupa perubahan sebesar 0.05 pu pada 1s. Perubahan yang dimaksudkan yaitu terjadi kenaikan dan penambahan beban. Kenaikan beban tersebut mengakibatkan perubahan daya elektrik juga akan bertambah. Apabila daya mekanik generator lebih besar dari daya elektrik maka dapat mengakibatkan percepatan pada rotor, percepatan rotor ini juga akan berpengaruh terhadap perubahan sudut rotor, sehingga respon sudut rotor akan turun atau negatif dari kondisi sebelum gangguan, ditunjukkan pada gambar 10. Respon yang diamati dari perubahan sudut rotor yaitu nilai overshoot dan settling time, seperti ditunjukkan pada tabel 4.

Tabel 4. Deviasi Sudut Rotor

\begin{tabular}{cc}
\hline Deviasi & Overshoot $(\mathrm{pu})$ \\
\hline SMIB & $-0.03651 \&-0.00874$ \\
SMIB-PID & $-0.01306 \&-0.03332$ \\
SMIB-PSS & $-0.01888 \&-0.02264$ \\
SMIB-PSS-PID & $-0.02093 \&-0.02197$ \\
\hline
\end{tabular}

Tabel 4 menunjukkan karakteristik overshoot sistem untuk kondisi perubahan beban pada detik ke-1. Sistem SMIB tanpa kontrol didapatkan overshoot sebesar $0.03651 \mathrm{~s} / \mathrm{d}-0.00874 \mathrm{pu}$ dengan settling time 18.88s. Sistem SMIB dengan kontrol PID didapatkan overshoot sebesar $0.01306 \mathrm{~s} / \mathrm{d}-0.03332 \mathrm{pu}$ dengan settling time 11.59s. Sistem SMIB dengan kontrol PSS didapatkan overshoot sebesar $0.01888 \mathrm{~s} / \mathrm{d}-0.02264 \mathrm{pu}$ dengan settling time 5.026s. Kemudian dengan metode yang diusulkan menggunakan PSS-PID didapatkan overshoot yang paling kecil yaitu $-0.02093 \mathrm{~s} / \mathrm{d}-0.02197 \mathrm{pu}$ dengan settling time $3.283 \mathrm{pu}$. 
Kemudian pada perubahan beban berikutnya berupa pengurangan beban pada detik ke-20. Pada kondisi ini daya mekanik generator lebih kecil dari daya elektrik, sehingga mengakibatkan perlambatan pada rotor, perlambatan rotor ini juga akan berpengaruh terhadap perubahan sudut rotor, sehingga respon sudut rotor akan naik atau positif dari kondisi sebelum gangguan. Hal ini terjadi karena kopel magnetis akan mendorong medan stator dengan medan rotor, Sehingga sudut rotor dari generator akan naik, seperti ditunjukkan pada gambar 10 . Karakteristik overshoot sistem pada kondisi ini ditunjukkan pada tabel 5 .

Tabel 5 menunjukkan karakteristik overshoot sistem untuk kondisi perubahan beban pada detik ke-20. Sistem SMIB tanpa kontrol didapatkan overshoot sebesar
$-0.01651 \mathrm{~s} / \mathrm{d}-0.002530$ pu dengan settling time 36.47s. Sistem SMIB dengan kontrol PID didapatkan overshoot sebesar $0.01437 \mathrm{~s} / \mathrm{d}-0.003934 \mathrm{pu}$ dengan settling time 129.55s. Sistem SMIB dengan kontrol PSS didapatkan overshoot sebesar $0.01145 \mathrm{~s} / \mathrm{d}-0.009567 \mathrm{pu}$ dengan settling time 23.54s. Kemudian dengan metode yang diusulkan menggunakan PSS-PID didapatkan overshoot yang paling kecil yaitu $-0.01113 \mathrm{~s} / \mathrm{d}-0.009669 \mathrm{pu}$ dengan settling time 22.36s.

Tabel 5. Deviasi Sudut Rotor

\begin{tabular}{cc}
\hline Deviasi & Overshoot $(\mathrm{pu})$ \\
\hline SMIB & $-0.01651 \&-0.002530$ \\
SMIB-PID & $-0.01437 \&-0.003934$ \\
SMIB-PSS & $-0.01145 \&-0.009567$ \\
SMIB-PSS-PID & $-0.01113 \&-0.009669$ \\
\hline
\end{tabular}

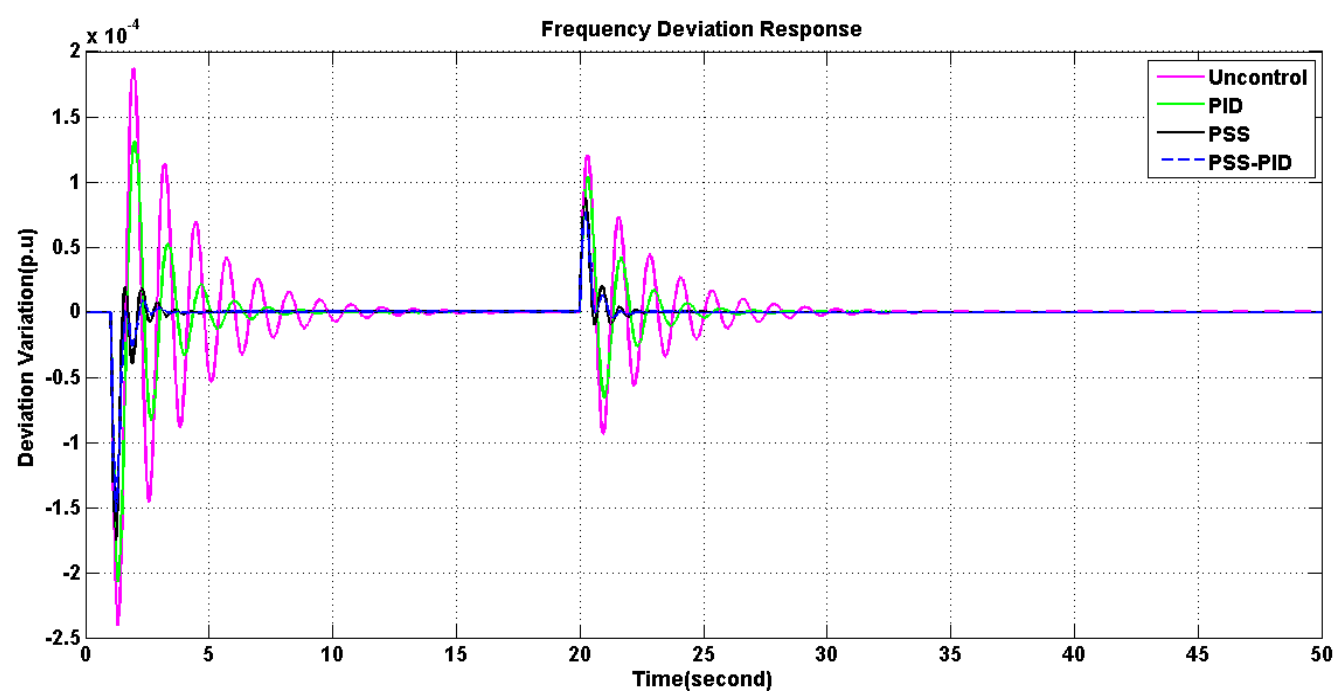

Gambar 9. Respon Frekuensi SMIB

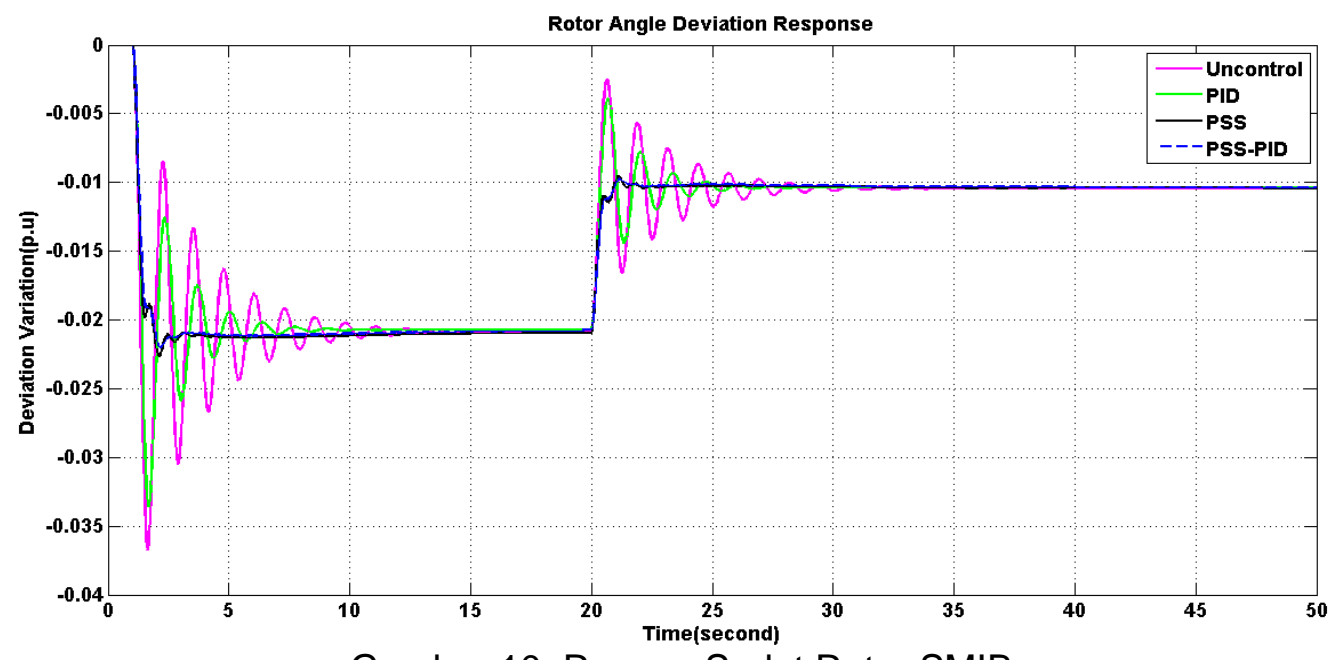

Gambar 10. Respon Sudut Rotor SMIB 


\section{SIMPULAN}

Dari hasil simulasi didapatkan parameter PSS-PID yang optimal dengan penalaan berbasis ant colony yaitu $\mathrm{Kp}=$ $5.0311, \mathrm{Ki}=1.1755, \mathrm{Kd}=1.0043, \mathrm{Kpss}=$ $64.1961, \mathrm{~T} 1=0.5266, \mathrm{~T} 2=0.2317, \mathrm{~T} 3=$ $1.0971, \mathrm{~T} 4=5.4010$.

Dengan penalaan optimal didapatkan respon frekuensi SMIB yang sempurna dibanding dengan sistem tanpa kontrol, SMIB-PID dan SMIB-PSS, hal ini ditunjukkan dengan respon sistem yang mengalami perbaikan, di mana kontroler mampu memberikan kestabilan sehingga osilasi overshoot diredam, serta kinerja settling time yang semakin cepat untuk sistem menuju ke kondisi steady state. Dengan penalaan parameter PSS-PID yang tepat, Overshoot yang terjadi pada sistem ini mampu di diredam.

\section{DAFTAR PUSTAKA}

Aliklas, Q., Satyahadewi, N., \& Perdana, H. Penerapan Algoritma Max-Min Ant Sistem Dalam Penyusunan Jadwal Mata Kuliah Di Jurusan Matematika FMIPA Untan. BIMASTER, 8(2).

Djalal, M. R., \& Faisal, F. (2020). Design Of Optimal PID Controller For Three Phase Induction Motor Based On Ant Colony Optimization. 2020, 24(2), 8. doi:10.22441/sinergi.2020.2.006

Djalal, M. R., Imran, A., \& Robandi, I. (2015). Optimal placement and tuning power sistem stabilizer using Participation Factor and Imperialist Competitive Algorithm in $150 \mathrm{kV}$ South of Sulawesi sistem. Paper presented at the Intelligent Technology and Its Applications (ISITIA), 2015 International Seminar on.

Djalal, M. R., Setiadi, H., Lastomo, D., \& Yunus, M. Y. (2017). Modal Analysis and Stability Enhancement of $150 \mathrm{kV}$ Sulselrabar Electrical Sistem using PSS and RFB based on Cuckoo Search Algorithm. International Journal on Electrical Engineering and Informatics, 9(4), 800-812.

Djalal, M. R., \& Sonong, S. (2018). Penalaan PSS pada Sistem Generator Tenaga Menggunakan Algoritma Penyerbukan Bunga. Jurnal Teknologi dan Sistem Komputer, 6(3), 93-99.

Djalal, M. R., Yunus, M. Y., Nawir, H., \& Imran, A. (2017). Application of Smart Bats
Algorithm for Optimal Design of Power Stabilizer Sistem at Sengkang Power Plant. International Journal of Artificial Intelligence Research, 1(2).

Djalal, M. R., Yunus, M. Y., Nawir, H., \& Imran, A. (2017). Optimal Design of Power Sistem Stabilizer In Bakaru Power Plant Using Bat Algorithm. 2017, 1(2), 6. doi:10.21070/jeee-u.v1i2.1017

Djalal, M. R., Yunus, M. Y., Setiadi, H., \& Krismanto, A. U. (2018). Small-SignalStability Enhancement using a PowerSistem Stabilizer based on the CuckooSearch Algorithm against Contingency $\mathrm{N}-1$ in the Sulselrabar 150-kV Sistem. Makara Journal of Technology, 22(1), 18.

Kundur, P. Power sistem stability and control (Vol. 7).

Laksono, H. D., \& Putra, I. R. (2013). Analisa Performansi Single Machine Infinite Bus (SMIB) dengan Metoda Linear Quadratic Regulator (LQR)(Studi Kasus: PLTA Singkarak). Teknika, 20(2).

Muhammad, R. D., \& Herman, H. (2019). Speed Control Series Dc Motor Using Ant Colony Optimization. Techno Journal, 20(2), 105-116.

Padiyar, K. R. (1996). Power Sistem Dynamics: John Wiley \& sons Ltd, Interlaine Publishing Ltd.

Robandi, I. (2009). Modern Power Sistem Control. Penerbit ANDI, Yogyakarta.

Suharto. (2015). Penalaan Power Sistem Stabilizer (Pss) Untuk Perbaikan Stabilitas Dinamik Pada Sistem Tenaga Listrik Menggunakan Bat Algorithm (Ba). (Undergraduate), ITS Surabaya.

Yunus, A. M. S., \& Djalal, M. R. (2019, 21-22 Oct. 2019). Optimal Tuning of PID Control on Single Machine Infinite Bus Using Ant Colony Optimization. Paper presented at the 2019 International Conference on Technologies and Policies in Electric Power \& Energy.

Yunus, M. Y., Djalal, M. R., \& Marhatang. (2017). Optimal Design Power Sistem Stabilizer Using Firefly Algorithm in Interconnected 150 kV Sulselrabar Sistem, Indonesia. International Review of Electrical Engineering (IREE), 12(3), 250-259. 